$17^{\text {th }}$ International Congress of Metrology, 08009 (2015)

DOI: $10.1051 /$ metrology / 201508009

(C) Owned by the authors, published by EDP Sciences, 2015

\title{
Traceability and metrological assurance of the unity of the measurements of the vibration and the accelerometry in Ukraine
}

\author{
V. Skliarov, Ir. Kolozinska \\ National Scientific Centre "Institute of Metrology", 42, Myronosytska Str., Kharkiv, 61002, Ukraine
}

Résumé. L'article fournit des informations sur le support métrologique de mesure des vibrations et de l'accéléromètre en Ukraine. Décrit les caractéristiques métrologiques de l'étalon primaire national de l'accéléromètre à trois composants. Les problèmes réels de la traçabilité dans accéléromètre sont effectuées.

\section{Introduction}

National Scientific Centre "Institute of Metrology" (NSC "IM") is the leading metrology organization in Ukraine on assurance of measurement in different branches of the national economy. The institute established and operates over than 50 state standards (NS) and secondary standards (SS), reproducing basic and derived SI units (see Figure 1). Metrological assurance of measurement uniformity in the field of acceleration includes reproduction, storage and transfer of the measurement units (acceleration) from NS to measuring instruments.

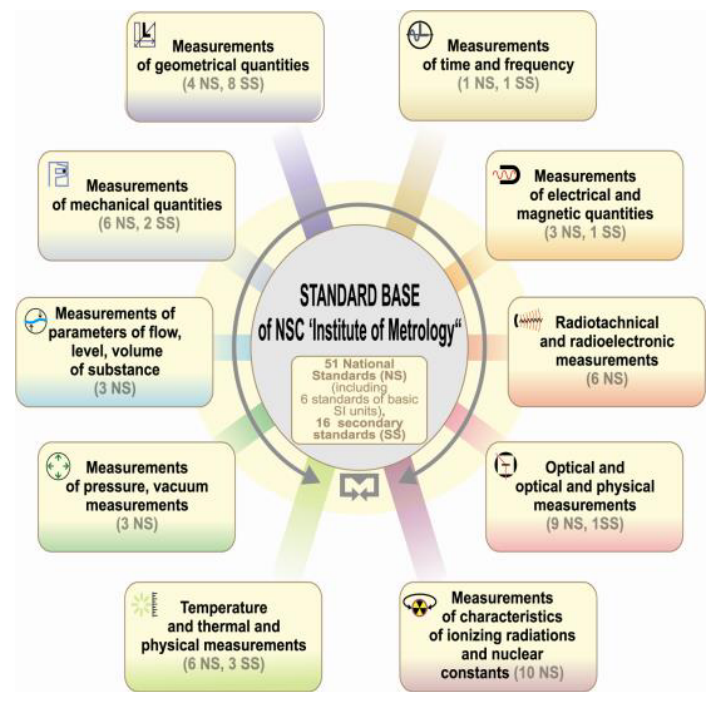

\section{The national primary standard}

In 2005 the NSC "IM" established the National primary standard of acceleration for the threecomponent accelerometer (see Figure 2).

The metrological characteristics of the standard are shown in Table 1.

The transfer unit size acceleration working means of measuring technique are as follows: seismic sensors, one-, two- and three-component accelerometers, increased accuracy is carried out by direct measurement according to the Ukrainian State verification schedule for vibration acceleration measuring means within the frequency range from $0.001 \mathrm{~Hz}$ to $10 \mathrm{~Hz}$ (DSTU 4452:2005).

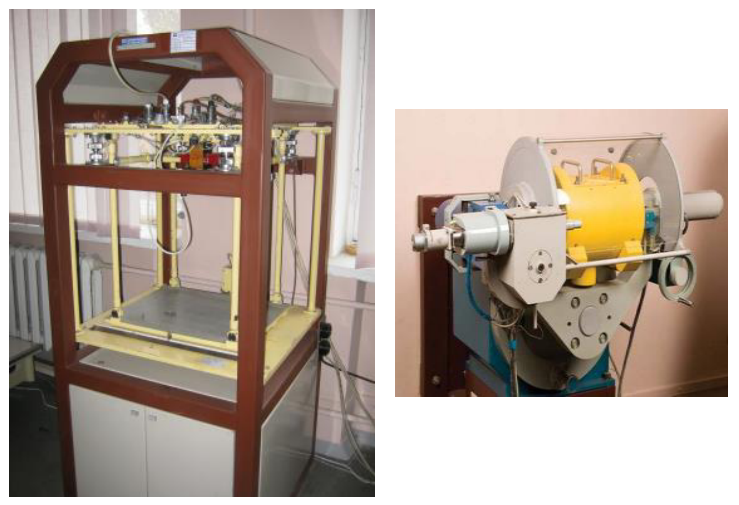

Figure 2. National primary standard of acceleration for the three-component accelerometer.

Figure 1. Standard base of the NSC 'Institute of Metrology" 
Table 1. The metrological characteristics of the NS

\begin{tabular}{|c|c|}
\hline \multicolumn{2}{|c|}{ Metrological characteristics } \\
\hline $\begin{array}{c}\text { The number of } \\
\text { playback components } \\
\text { of the acceleration } \\
\text { vector }\end{array}$ & 3 \\
\hline $\begin{array}{c}\text { The frequency range of } \\
\text { accelerations }\end{array}$ & from $1 \mathrm{~Hz}$ to $35 \mathrm{~Hz}$ \\
\hline $\begin{array}{c}\text { Dynamic range of the } \\
\text { measurement }\end{array}$ & от $0,005 \mathrm{~m} / \mathrm{c}^{2}$ до 9,8 \\
$\mathrm{~m} / \mathrm{c}^{2}$
\end{tabular}

At creation of the standard the problem was solved by raising the level of safety of nuclear power plants and the creation of a number of systems for protection of Ukrainian NPPs from the influence of possible seismic impacts.

In NSC "IM" there was designed and organized mass production of anti-seismic protection of NPP equipment, that allows turning off the nuclear reactor in case of seismic shocks in the zone of the power units. The above mentioned equipment is installed and operated at power Ukrainian NPPs.

The applied work at the enterprises of the fuel and energy complex and the requirements of European technical regulations were an effective incentive for the expansion of calibration and measurement capabilities of accredited laboratories, and the motivation to improve the NS.

The aim of upgrading of the standard was to expand the range of the transmission unit of acceleration and bandwidth by retrofitting high-precision equipment (see Table 2).

Table 2. New possibilities of the National primary standard

\begin{tabular}{|c|c|c|}
\hline \multirow[b]{2}{*}{$\begin{array}{l}\text { Measuring } \\
\text { instruments }\end{array}$} & \multicolumn{2}{|c|}{ Metrological characteristics } \\
\hline & $\begin{array}{l}\text { Measurement } \\
\text { range }\end{array}$ & $\begin{array}{l}\text { The } \\
\text { boundaries } \\
\text { of the } \\
\text { expanded } \\
\text { uncertainty }\end{array}$ \\
\hline $\begin{array}{l}\text { Accelerometers } \\
\text { and seismic } \\
\text { sensors }\end{array}$ & $\begin{array}{c}\text { frequency } \\
\text { from } 0,001 \mathrm{~Hz} \\
\text { to } 7000 \mathrm{~Hz} \\
\text { accelerations } \\
\text { from } 0,005 \\
\mathrm{~m} / \mathrm{c}^{2} \text { to } 430 \\
\mathrm{~m} / \mathrm{c}^{2} ; \\
\text { speed up to } \\
1,5 \mathrm{~m} / \mathrm{c} \\
\text { displacements } \\
\text { up to } 15 \mathrm{~mm}\end{array}$ & $\begin{array}{c}\mathrm{U}=0,1 \% \\
\mathrm{U}=(0,1- \\
10) \% \\
\mathrm{U}=4 \% \\
\mathrm{U}=4 \%\end{array}$ \\
\hline
\end{tabular}

\section{Actual problems}

Actual problems in the area of traceability in vibrometry can be divided into several areas.

1. Creation and metrological support of the equipment to ensure the safety of working Ukrainian NPPs. The need for vibration monitoring system defined regulatory requirements and the production of documents to security systems and systems important to safety:

- systems of anti-seismic protection industrial of the complex emergency and preventative protection;

- vibration monitoring systems and turbines;

- automated system for vibromonitoring of the main circulation pumps.

The creation of vibratory working standards for certification and calibration of accelerometers and seismic sensors Ukrainian NPPs on site complies with the requirements of international instruments (ISO 10816, ISO 7919, ISO 13374, ISO 13379, ISO 13380, ISO 13381) [1-5] control range of operating frequencies NPP equipment in the range of $0.1 \mathrm{~Hz}$ to $1000 \mathrm{~Hz}$ with the boundaries of the basic reduced error not exceeding 1\%. The range of seismic activity predetermines the use for calibration, verification and validation test benches seismic sensors with the range of frequencies test from $0.1 \mathrm{~Hz}$ to $7 \mathrm{kHz}$.

2. The implementation of public acceptance test vibration monitoring systems for machinery safety of Ukrainian enterprises. Acceptance tests include determining of the metrological characteristics of the systems under normal and extreme conditions (high temperature and humidity, voltage deviations); determination of the stability of metrological characteristics of the systems under the influence of external vibration and shock vibrations; testing of the electromagnetic compatibility and electrical safety as well as the stability of the systems under the effect of transport conditions.

3. Development of a network of the railway transport of Ukraine determines the compliance with the international standards for the transport of dangerous goods [6, 7]. The Manual for Tests and Criteria of work including the vibration diagnostics of rolling stock. During preparation for the testing of the rolling stock there is carried out $3 \mathrm{D}$ modeling of the test subjects indicating the placement of accelerometers points (see Figure 3). 


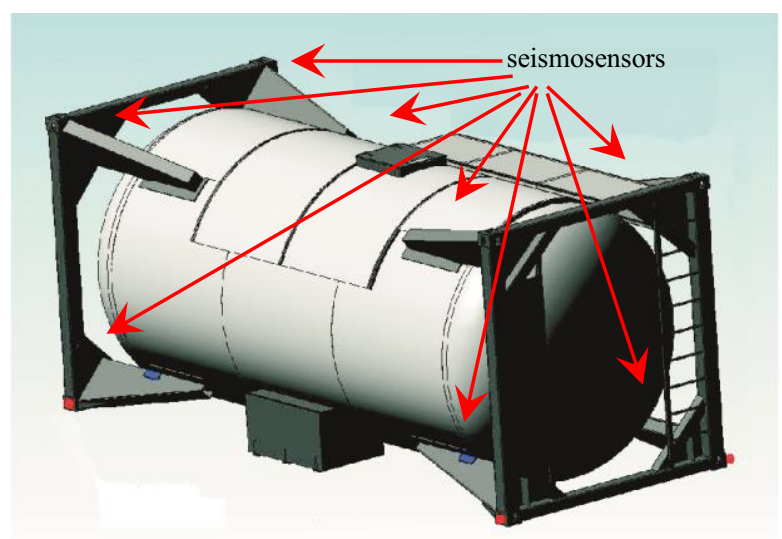

Figure 3. 3D model of the object

The 3D model of the object is calculated by the finite element method software package ANSYS. The comparison of calculated and experimental data allows us to make a conclusion about the correctness of the results and about the applicability of the object for use.

\section{Conclusion}

The works on verification, validation, and calibration of the accelerometers and seismic sensors in the field vibrometry in Ukraine are performed in compliance with traceability to the state standards. The measuring equipment used at work with the NS calibration certificate. The laboratory equipment is necessary at carrying out of the vibrometry safety testing according to the Directive 2006/42/EC [8].

\section{References}

1. ISO 10816 Mechanical vibration - Evaluation of machine vibration by measurements on non-rotating parts.

2. ISO 7919 Mechanical vibration - Evaluation of machine vibration by measurements on rotating shafts.

3. ISO 13374 Condition monitoring and diagnostics of machine systems.

4. ISO 13379 Condition monitoring and diagnostics of machines.

5. ISO 13381 Condition monitoring and diagnostics of machines.

6. ST/SG/AC.10/11/Rev 5 Transportation of dangerous goods.

7. ISO 6487:2002 Road vehicles. Measurement techniques in impact tests.

8. 2006/42/EC Declaration of conformity to "Safety of machinery". 